\title{
Passive smoking interference with wheezing and asthma: short review of current knowledge
}

\author{
Yousser Mohammad ${ }^{1,2}$ \\ Correspondence: ccollaborating@gmail.com

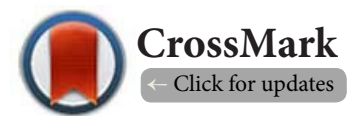

${ }^{1}$ National Center for Research in Chronic Respiratory Diseases, Tishreen University School of Medicine, Latakia, Syria.

${ }^{2}$ Department of Internal Medicine, Chest Diseases Section, Syrian Private University, Syria.

\begin{abstract}
In 2006, the US general surgeon reported that exposure to (ETS) in early life is causal for wheezing. Although the role of ETS in asthma onset was still inconclusive. However a report by International Study of Asthma and Allergies in childhood published in 2012 suggested that the relationship is causal. Particles present in ETS are of smaller size $(0.1 \mu \mathrm{m})$ which allows them to penetrate deeply into the lungs resulting in oxidative stress and the liberation of Oxidative Reactive Substances, which are among the most aggressive mechanisms for airway inflammation. There are susceptibility genes for asthma in predisposed individuals, however clinical expression might not be apparent unless there is appropriate environmental exposure such as inhalation of parental ETS by children or exposure to allergens. This exposure to ETS leads to epigenetic changes. Epigenetic changes are defined as heritable changes that affect gene expression without altering the DNA sequence. ETS seems to influence innate immunity predisposing to Th2associated respiratory diseases and increasing the risk for IgE-mediated sensitization, which could lead to the inflammatory and structural changes seen in allergic diseases, especially asthma. Exposure to water pipe ETS (locally called Narghile, Shisha, or Hookah) is to be considered especially in the Middle East. We hope the next WHO report would consider the harm of in-home environmental tobacco smoke exposure, and the need to protect the rights of children worldwide.
\end{abstract}

Keywords: Environmental tobacco smoke, ETS, wheezing, asthma, epigenetics, IgE, waterpipe, narghile

\section{Introduction}

The relationship between passive smoking and the development of hyperactive airway disease is the subject of intense investigation. In 2006, the US general surgeon reported that exposure to Environmental Tobacco Smoke (ETS) in early life is causal for wheezing [1]. Although the same report indicated that the role of ETS in asthma onset was still inconclusive [1], a report by International Study of Asthma and Allergies in childhood (ISAAC) published in 2012 suggested that the relationship is causal [2]. The Syrian center of ISAAC reported that exposure to narghile smoke has stonger association with wheezing than exposure to cigarette ETS [3].

In this short review, we will illustrate components of Environmental Tobacco Smoke (ETS) from cigarettes, then summarize current knowledge on the mechanisms involved in the pathogenesis of wheezing and asthma following exposure to ETS. We will as well give the essential on ETS of waterpipe. Full description of waterpipe is given by Chaouachi K [4].

\section{Discussion}

What is ETS?

There are several components of smoke generated by a burning cigarette. First, there is Mainstream Smoke (MSS) which is generated at the cold tip of the cigarette and inhaled directly by the smoker. Second, the side stream smoke (SSS) which is generated at the burning end of the cigarette and emitted directly into the atmosphere. Finally, there is the smoke exhaled by the smoker after inhaling the MSS. This exhaled smoke is referred to as the Exhaled Mainstream Smoke (EMSS). ETS consists of both SSS and EMSS and is inhaled by passive smokers as well as smokers. Smokers, in addition to inhaling MSS, are also exposed to ETS $[2,5]$.

Wirth, in a general review [5], reported cigarette ETS to be more toxic than MSS for several reasons. ETS has a low ignition temperature $\left(600^{\circ}-800^{\circ}\right)$. In addition, several toxic substances such as carbon monoxide, nicotine, volatile organic compounds and benzopyrenes are present in higher concentrations. Finally, particles present in ETS are of smaller size $(0.1 \mu \mathrm{m})$ which allows them to penetrate deeply into the lungs resulting in oxidative stress and the liberation of Oxidative Reactive Substances, which are among the most critical mediators for airway inflammation [6]. The same for narghile ETS [7]. A comprehensive comparative table between MSS and ETS of cigarettes "Environmental Tobacco Smoke: Measuring 
Exposures and Assessing Health Effects, 1986" is quoted with permission from National Academy of Sciences, Courtesy of the National Academies Press, Washington, D.C. could be reviewed in the link:http://www.ncbi.nlm.nih.gov/books/ NBK219205/[8].

Clouds of Narguile ETS is composed almost only by (EMSS), because the ignition temperature is low $200^{\circ}-380^{\circ}$, consequently smoking product is incompletely burned but especially heated, Narguile smoke is more rich in $\mathrm{CO}$, while nicotine and particles are partially filtered by water [4].

Middle East researchers have subsequently estimated the overall waterpipe water-filtration rate to be $38 \%$ and concluded that only 142 compounds are detected in a waterpipe, which is actually far less complex than cigarette smoke. This figure can be compared with the 4,700 substances identified so far in cigarette smoke [4].

However, the WHO report 2015 cited that, on a smoker hour basis, waterpipe smoking results in higher emissions of $\mathrm{CO}$, Poly Aromatic Hydrocarbure and volatile aldehydes than cigarette smoking [9].

\section{Pathogenesis and mechanisms}

Several factors are known to influence the functional, structural and immunological changes found in ETS exposed lungs of asthmatics $[10,11]$. Among these are the following:

\section{Genetic mechanisms}

The Genome Wide Associated Survey (GWAS) identified diverse genetic polymorphisms associated with asthma development [12]. Despite genetic predisposition to allergy and asthma, resulting from the presence of several susceptibility genes in many individuals. Expression of these genotypes, however, is variable. Not all individuals with genetic predisposition express airway hyper reactivity. Clinical expression in individuals with sucseptible genes might not be apparent unless there is an appropriate environmental exposure such as inhalation of ETS by children of smoking adults or exposure to allergens $[10,12,13]$.

Environmental exposure of individuals with susceptible genes leads to epigenetic changes. Epigenetic changes are defined as heritable changes that affect gene expression without altering the DNA sequence $[12,13]$. Epigenetic regulation of gene expression is facilitated by different mechanisms such as DNA methylation, histone modifications, RNA-associated silencing by small non-coding RNAs, phosphorylation and

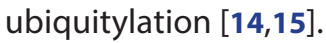

What is the evidence for genetic polymorphisms in asthma? Several studies have identified possible susceptibility genes in asthma. These include:

In a genome wide linkage analysis [5], regions of DNA of these susceptibility genes in chromosomes $5 q, 1 P$ and $9 q[16]$ were found to carry risk of developing asthma when exposed to ETS in utero or post natal exposure. In these subjects, ETS exposure may lead to epigenetic changes which will program the genome without changing DNA.

ETS in utero and postnatal exposure leads to epigenetic methylation of 17q21 locus, which might program an individual toward atopic disease. Epigenetic phenomena might contribute to a $\mathrm{TH} 1$ and $\mathrm{TH} 2$ imbalance and epigenetic changes could be transmitted through generations $[6,16]$.

In utero or postnatal exposure to ETS is causal for wheezing in children especially with the Arg16Arg genotype or 2 copies of the Arg16-Gln27 diplotype [17].

The genotype with deficiency in glutathione 5 transferase is at risk of developing asthma when exposed to ETS inutero [5]. Interleukin 13 receptor gene antagonist is blocked by ETS exposure [18].

In addition, other genes with potential interactions with tobacco smoking and risk for asthma exacerbations have been identified in candidate gene linkage approaches [19-22].

\section{Immunologic mechanisms}

Several immunologic factors seem to be involved in ETS related airway hyperresponsiveness. These include the following:

ETS seems to influence innate immunity predisposing to Th2-associated respiratory diseases and increasing the risk for IgE-mediated sensitization $[5,10,13]$ which could lead to the inflammatory and structural changes seen in allergic diseases, especially asthma.

Leukotrienes are increased in urine of asthmatic children exposed to ETS and viral infections are frequent. Vulnerability to viral infections and leukotriene upregulation are the most probable mechanisms in ETS-induced immunological mechanisms [23].

After exposure to ETS, bronchial hyper responsiveness can be demonstrated for several weeks indicating persistent airway inflammation. Exposure to ETS raises the lgE level in blood, even in individuals with no family history of asthma [24]. The essential of these mechanisms is illustrated in the Figure 1. In the neonate umbilical cord of mother that smokes, there are high levels of IgE $[\mathbf{5 , 2 4 ]}$.

Recent research showed ETS influences the activities of dendritic cells, which are antigen presenting cells [25].

In animals Application of mouse models of IgE-mediated allergic asthma has provided evidence for a role of air pollutants (ozone, diesel exhaust, environmental tobacco smoke) in enhanced sensitization to allergens. These responses are mediated by immunoglobulin $\mathrm{E}(\mathrm{IgE})$ antibodies that bind to mast cells and cause release/synthesis of potent mediators [26]. Perinatal ETS exposure also significantly increased IL 5 , the numbers of mast cells, eosinophils, monocytes and lymphocytes in the lungs of infant monkeys. In addition, ex vivo measurements Perinatal ETS exposure can induce a $\mathrm{T}(\mathrm{H}) 2$ biased inflammatory response and alter airway innervation in infant monkeys [27]. In Humans, Mast cells are leukocytes that are effectors of the inflammatory process: Dendretic cells present the antigene (allergen) to $T$ helper 2 lymphocytes in the airway lumen, following a cascade of events will lead to 


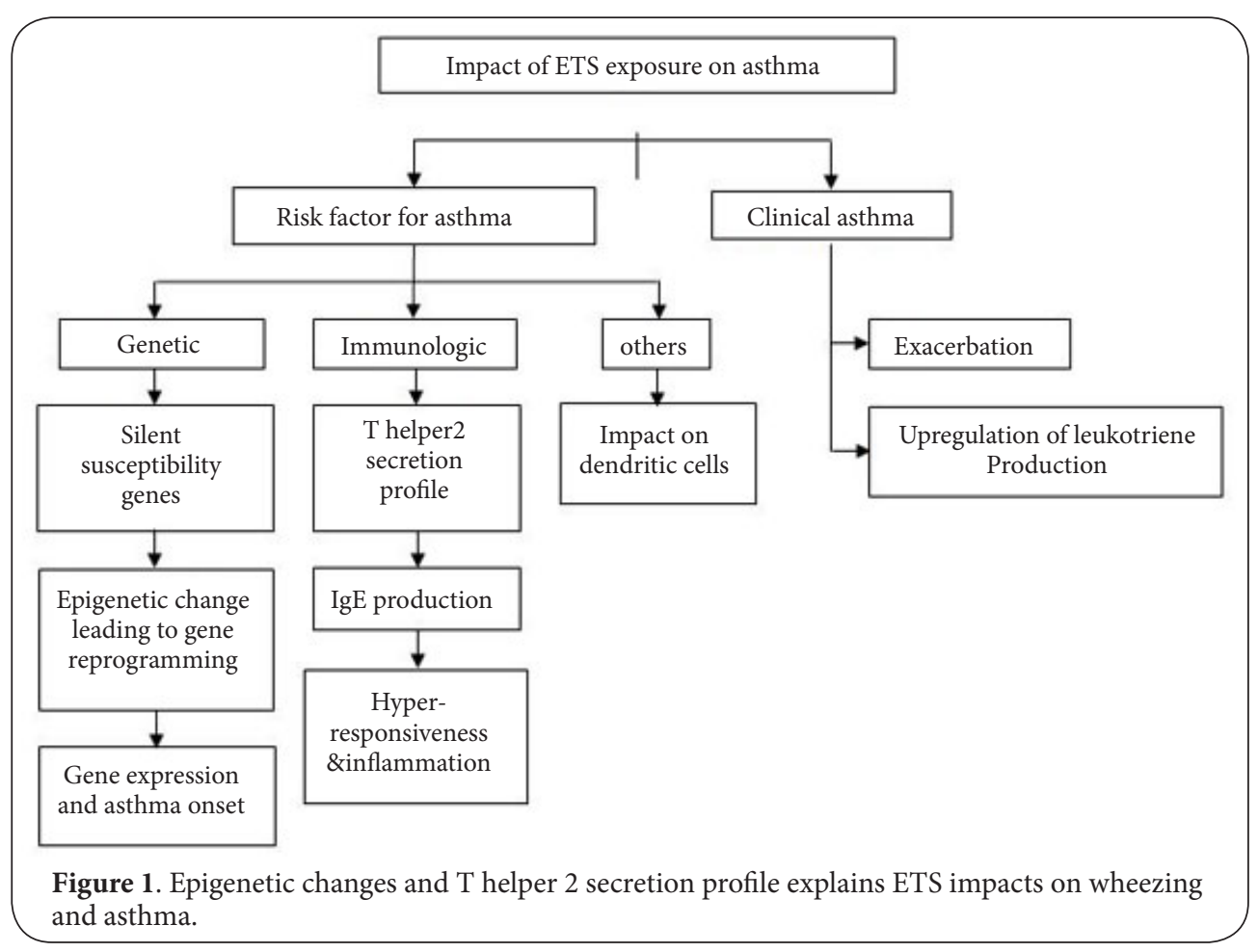

specifique $\lg E$ secretion, eosinophils activation and mast cells degranulation followed by prostaglandine and leukotrienes synthesis. These mechanisms lead to chronic inflammation, bronchial hyper-responsivnesse and remodeling $[\mathbf{2 8 , 2 9 ]}$. Epithelial cells also play a role [29].

The information described above which strongly links ETS to airway hyper responsiveness, leads us to strongly recommend Public Health campaigns to limit infant and children exposure to ETS at home. We believe that resources currently dedicated to molecular, genetic or epidemiologic research on the detrimental effects of active and passive smoking should be utilized to pass legislation to implement smoke free home policies to protect children and other non-smokers. This would expand the approach taken by the World Health Organization Framework Convention on Tobacco Control which issued four reports on the Global Tobacco Epidemic in 2008, 2009, 2011 and 2013. Interestingly, the 2009 report [30] focused on legislation to promote smoke free work place and public places to protect non smokers, but did not mention ETS in the home. The report issued in 2013 [31] also neglected to address smoking and ETS at home. This report, which focused on legislation to create smoke-free zones globally, ban advertising and sponsorship by tobacco industry and increase taxation of tobacco products, found that despite inconsistent implementation of adopted legislation, major improvement in protecting the public has been realized. We hope the next WHO report would build on these positive outcomes and consider the harm of in-home environmental tobacco smoke exposure, taking into consideration the accumulating evidence [1-25], the premiere role of WHO in global public health and the need to protect the rights of children worldwide.

Especially when we know that. There is no impact of commonly used air filters (MERV 4 and MERV 8) in eliminating the exposure to second hand smoke constituents like carbon monoxide levels or PM 2.5, which have been correlated with human health toxicity/disease [32]. And that former surveys, like the post legislation survey in Wales in 2008-repeated in2014, which examines changes in restrictions on smoking in cars and homes and child exposure to secondhand smoke in these locations, showed that children reported significant lower exposure to ETS in 2014 [33]. A survey in China showed that helping caregivers quitting smoke combined with classroombased health education was effective in reducing children's environmental tobacco smoke exposure; children's urinary cotinine was significantly lower $(p=0.002)$ and caregivers' quit rate was significantly higher $(p<0.001$; adjusted $O R=1.13$; $95 \% \mathrm{Cl}: 1.02-1.26)$ in the intervention than control group [34].

\section{Conclusion}

In predisposed individuals for asthma, Susceptibility genes,are reprogrammed by Epigenetic changes resulting from exposure to ETS in early life, leading to hyper-responsiveness, allergy and asthma $[10,12,13]$.

ETS exposure also modulate immunity in favor of Thelper 2 cells, leading to IgE secretion [24].

Legislations to protect children should consider in-home exposure to ETS, especially when we know that air filters used 
to eliminate ETS constituents like carbon monoxide levels or PM 2.5, which have been correlated with human health toxicity/disease. are not efficient [32]. We hope the coming WHO report will consider this right of non exposure to ETS at home for children. Methodes like caregivers quitting smoke combined with classroom based education could play a positive role in reducing exposure [33]. Baning smoking in cars transporting children as well [34]. Waterpipe should be considered in all legislation initiatives to protect children from ETS [9].

\section{Competing interests}

The author declares that he has no competing interests.

\section{Acknowledgement}

I thank the University Councils of The Syrian Private University and Tishreen University for supporting and sponsoring our projects in research and publications.

\section{Publication history}

Editors: Basil O. Ibe, Harbor-UCLA Medical Center, USA.

Jennifer Quint, London School of Hygiene \& Tropical Medicine, UK. EIC: Victor J. Thannickal, University of Alabama at Birmingham, USA.

Received: 12-Mar-2015 Final Revised: 14-May-2015

Accepted: 23-May-2015 Published: 01-Jun-2015

\section{References}

1. US general Surgeon. United States Surgeon General (2006) The health consequences of involuntary exposure to tobacco smoke. The US Department of Health and Human Services.

2. Mitchell EA, Beasley R, Keil U, Montefort S and Odhiambo J. The association between tobacco and the risk of asthma, rhinoconjunctivitis and eczema in children and adolescents: analyses from Phase Three of the ISAAC programme. Thorax. 2012; 67:941-9. | Article | PubMed

3. Mohammad Y, Shaaban R, Hassan M, Yassine F, Mohammad S, Tessier JF and Ellwood P. Respiratory effects in children from passive smoking of cigarettes and narghile: ISAAC Phase Three in Syria. Int J Tuberc Lung Dis. 2014; 18:1279-84. | Article | PubMed

4. Chaouachi K. Hookah (Shisha, Narghile) Smoking and Environmental Tobacco Smoke (ETS). A critical review of the relevant literature and the public health consequences. Int J Environ Res Public Health. 2009; 6:798843. | Article | PubMed Abstract | PubMed Full Text

5. Wirth $N$, Bohadana $A$, Spinosa $A$ and Martinet $Y$. [Respiratory diseases related to passive smoking]. Rev Mal Respir. 2009; 26:667-78. I PubMed

6. Bouzigon E, Corda E, Aschard H, Dizier MH, Boland A, Bousquet J, Chateigner N, Gormand F, Just J, Le Moual N, Scheinmann P, Siroux V, Vervloet D, Zelenika D, Pin I, Kauffmann F, Lathrop M and Demenais F. Effect of 17q21 variants and smoking exposure in early-onset asthma. $N$ Engl J Med. 2008; 359:1985-94. | Article | PubMed

7. Al-numair $\mathbf{k}$, barber-heidal $\mathbf{k}$, al-assaf a and el-desoky $\mathbf{g}$. Water-pipe (shisha) smoking influences total antioxidant capacity and oxidative stress of healthy Saudi males. International journal of food, agriculture and environment. 2007; 5:17-22. | Article

8. American pess. Environmental Tobacco Smoke: Measuring Exposures and Assessing Health Effects. National Research Council (US) Committee on Passive Smoking. Washington (DC): National Academies Press (US); 1986. Copyright $\odot 1986$ by the National Academy of Sciences. I Book

9. Advisory note. Waterpipe tobacco smoking: health effects, research needs and recommended actions for regulators. $2^{\text {nd }}$ edition. WHO Study Group on Tobacco Product Regulation (TobReg). (NLM classification: QV 137)@ World Health Organization 2015. I Website

10. Baena-Cagnani CE, Gomez RM, Baena-Cagnani R and Canonica GW.
Impact of environmental tobacco smoke and active tobacco smoking on the development and outcomes of asthma and rhinitis. Curr Opin Allergy Clin Immunol. 2009; 9:136-40. | Article | PubMed

11. Castro $M$ and Kraft M. Clinical asthma ( $\mathbf{1}^{\text {st }}$ edn), Philadelphia. Elserviermosby. 2008. | Book

12. Myers D. Mechanisms of asthma and allergies, What we learned. J Allergy ClinImmunol. 2010; 128:440-446.

13. Anto JM, Pinart M, Akdis M, Auffray C, Bachert C, Basagana X, Carlsen KH, Guerra S, von Hertzen L and Illi $S$ et al. Understanding the complexity of IgE-related phenotypes from childhood to young adulthood: a Mechanisms of the Development of Allergy (MeDALL) seminar. J Allergy Clin Immunol. 2012; 129:943-54. | Article | PubMed

14. Madore AM and Laprise $C$. Immunological and genetic aspects of asthma and allergy. J Asthma Allergy. 2010; 3:107-21. | Article | PubMed Abstract | PubMed Full Text

15. Mortaz E, Masjedi MR, Barnes PJ and Adcock IM. Epigenetics and chromatin remodeling play a role in lung disease. Tanaffos. 2011; 10:716. | PubMed Abstract | PubMed Full Text

16. Colilla S, Nicolae D, Pluzhnikov A, Blumenthal MN, Beaty TH, Bleecker ER, Lange EM, Rich SS, Meyers DA, Ober C and Cox NJ. Evidence for geneenvironment interactions in a linkage study of asthma and smoking exposure. J Allergy Clin Immunol. 2003; 111:840-6. | Article | PubMed

17. Wang C, Salam MT, Islam T, Wenten M, Gauderman WJ and Gilliland FD. Effects of in utero and childhood tobacco smoke exposure and beta2adrenergic receptor genotype on childhood asthma and wheezing. Pediatrics. 2008; 122:e107-14. | Article | PubMed Abstract | PubMed Full Text

18. Ramadas RA, Sadeghnejad A, Karmaus W, Arshad SH, Matthews S, Huebner M, Kim DY and Ewart SL. Interleukin-1R antagonist gene and pre-natal smoke exposure are associated with childhood asthma. Eur Respir J. 2007; 29:502-8. | Article | PubMed Abstract | PubMed Full Text

19. Kurz $T$ and Ober $C$. The role of environmental tobacco smoke in genetic susceptibility to asthma. Curr Opin Allergy Clin Immunol. 2004; 4:335-9. | Article | PubMed

20. Karjalainen J, Hulkkonen J, Nieminen MM, Huhtala H, Aromaa A, Klaukka $T$ and Hurme M. Interleukin-10 gene promoter region polymorphism is associated with eosinophil count and circulating immunoglobulin $E$ in adult asthma. Clin Exp Allergy. 2003; 33:78-83. | Article | PubMed

21. Joos L, McIntyre L, Ruan J, Connett JE, Anthonisen NR, Weir TD, Pare PD and Sandford AJ. Association of IL-1beta and IL-1 receptor antagonist haplotypes with rate of decline in lung function in smokers. Thorax. 2001; 56:863-6. | PubMed Abstract | PubMed Full Text

22. Lang JE, Dozor AJ, Holbrook JT, Mougey E, Krishnan S, Sweeten S, Wise RA, Teague WG, Wei CY, Shade D and Lima JJ. Biologic mechanisms of environmental tobacco smoke in children with poorly controlled asthma: results from a multicenter clinical trial. J Allergy Clin Immunol Pract. 2013; 1:172-80. | Article | PubMed

23. Waston RR and Witten M. Environmental Tobacco Smoke. by CRC Press LLC. International Standard Book Number 0-8493-0311-7. Library of Congress Card Number 00-057190. 2001.

24. Gill MA. The role of dendritic cells in asthma. J Allergy Clin Immunol. 2012; 129:889-901. | Article | PubMed

25. Pritsos CA and Muthumalage T. The impact of commonly used air filters in eliminating the exposure to secondhand smoke constituents. Environ Sci Process Impacts. 2015; 17:543-51. | Article | PubMed

26. Gershwin LJ. Comparative immunology of allergic responses. Annu Rev Anim Biosci. 2015; 3:327-46. | Article | PubMed

27. Yu M, Zheng $X$, Peake J, Joad JP and Pinkerton KE. Perinatal environmental tobacco smoke exposure alters the immune response and airway innervation in infant primates. J Allergy Clin Immunol. 2008; 122:640-7. | Article | PubMed

28. From the Global Strategy for Asthma Management and Prevention. Global Initiative for Asthma (GINA). 2015. I Website

29. Pascal Chanez and Arnaud Bourdin. Physiopathology of asthma. In: Clinical asthma. Mario Castro and Monica Craft. Elsevier. 2008; 22-33.

30. Rapport de l'OMS sur l'epidemiologie Mondiale de Tabagisme Mise en 
place d'espace non fumeur. 2009.

31. WHO REPORT on the Global Tobacco Epidemic Enforcing bans on tobacco advertising, promotion and sponsorship. 2013. | Pdf

32. Pritsos CA and Muthumalage T. The impact of commonly used air filters in eliminating the exposure to secondhand smoke constituents. Environ Sci Process Impacts. 2015; 17:543-51. | Article | PubMed

33. Wang $Y$, Huang $Z$, Yang $M$, Wang $F$ and Xiao $S$. Reducing environmental tobacco smoke exposure of preschool children: a randomized controlled trial of class-based health education and smoking cessation counseling for caregivers. Int J Environ Res Public Health. 2015; 12:692-709. | Article | PubMed Abstract | PubMed Full Text

34. Moore GF, Moore L, Littlecott HJ, Ahmed N, Lewis S, Sulley G, Jones E and Holliday J. Prevalence of smoking restrictions and child exposure to secondhand smoke in cars and homes: a repeated cross-sectional survey of children aged 10-11 years in Wales. Less cotinine in urine six month later. BMJ Open. 2015; 5:e006914. | Article

\section{Citation:}

Mohammad Y. Passive smoking interference with wheezing and asthma: short review of current knowledge. Pulmonol Respir Res. 2015; 3:2. http://dx.doi.org/10.7243/2053-6739-3-2 